\title{
EENIGE BIJZONDERHEDEN OMTRENT MEVROUW AUDRA EN HAAR ZOON
}

DOOR

\section{K. KESLER $\dagger$}

Mevrouw Audra is voor degenen, die met de geschiedenis van Suriname eenigszins vertrouwd zijn, een bekende en zelfs een min of meer beruchte figuur. Bekend is de wijze, waarop zij met eenige andere vooraanstaande leden der Surinaamsche samenleving in het midden der $18 \mathrm{e}$ eeuw den gouverneur Mauricius het leven zuur maakte en het ten slotte met haar medestanders, mannelijke zoowel als vrouwelijke, zoo ver wist te sturen, dat van hoogerhand moest worden ingegrepen en uit de Republiek een commissie werd gezonden, om de Surinaamsche zaken te onderzoeken en aan de troebelen daar een einde te maken.

Dat was in 1750. Mevrouw Audra, of, zooals zij destijds heette, Mevro iw Duvoisin, was toen op den leeftijd van vijftig jaar een eerzame, hoewel zeer militante, predikants-weduwe. Het weduwekleed droeg zij reeds voor de vierde maal, maar desniettemin zou zij het nog eenmaal voor het bruids-gewaad verwisselen en niet lang daarna ook haar vijfden echtgenoot ten grave zien dalen en hem nog eenige jaren overleven.

Geboren in den Haag op 19 November 1700 als dochter van den Hoogduitschen predikant te 's-Gravenhage, was Charlotte Elisabeth van der Lith tijdens het bewind van den gouverneur Hendrik Temminck (1722-1727) gouvernante van diens dochter Catharina Eleonora geweest. Deze betrekking leidde ertoe, dat Gouverneur Temminck, die weduwnaar was, besloot de gouvernante ten huwelijk te vragen. De echtverbintenis werd te Paramaribo gesloten, doch was niet van langen duur, daar gouverneur Temminck op 17 September 1727 overleed, zijn jonge vrouw met een dochtertje, Johanna Balfina, achter latende.

Nog tweemaal zou zij daarna weder als echtgenoote van een gouverneur op het Plein te Paramaribo zetelen, eerst door haar huwelijk met den opvolger van Temminck, Mr. Charles Emilius

$$
-33-
$$


Henry de Cheusses. Deze overleed te Paramaribo op 26 Januari 1735 en liet zijn weduwe achter met een dochtertje, Henriëtte Maria. $\mathrm{Na}$ het zeer kortstondige bewind van zijn broeder Jacob Alexander Henry de Cheusses, die slechts gedurende $11 / 2$ maand de waardigheid van gouverneur bekleedde, en na een kort interimbestuur kwam in het laatst van 1735 de Amsterdammer Mr. Joan Raye als gouverneur in Suriname aan.

Mr. Joan Raye was de oudste zoon van Jan Raye, Heer van Breukelerwaard, een zeer welgesteld suiker-raffinadeur te Amsterdam, nakomeling van een Antwerpschen koopman, die zich in 1588 te Amsterdam vestigde, en daar op 20 October van dat jaar als poorter beëedigd werd.Gelijk zoovele andereVlamingen en Walen was hij om des geloofs wille uit de Zuidelijke naar de Noordelijke Nederlanden geëmigreerd. Uit het huwelijk van zijn afstammeling en naamgenoot Jan Raye, Heer van Breukelerwaard, met Aletta Catharina Bicker werden drie kinderen geboren, twee zoons Joan en Jacob, en een dochter Eva.

Hoewel de familie Raye niet tot de regeerende geslachten van Amsterdam behoorde, was zij toch door huwelijken nauw genoeg met deze verbonden, om mede te genieten van de voordeelen, die deze positie aan de $18 \mathrm{e}$ eeuwsche regenten verschafte. Na zijn studiën voltooid te hebben, verkreeg dan ook de oudste zoon Joan naast zijn functie van kapitein ter zee bij de Admiraliteit van Amsterdam ter verbetering van zijn inkomen in 1718 het baantje van afslager aan de Groote Vischmarkt. Er werd natuurlijk niet van hem verwacht, dat hij de daaraan verbonden werkzaamheden zelf zou verrichten; naar 18e-eeuwsche regenten-gewoonte liet hij deze waarnemen door een plaatsvervanger en streek de niet onbelangrijke inkomsten voor het grootste gedeelte zelf op. Deze bedroegen, zooals zijn broeder Jacob, die na hem dit baantje verkreeg, in zijn dagboek noteerde, $2^{1 /} / 2 \%$ van de opbrengst van de verkochte visch, wat een bedrag van 500 à 1000 gld. per maand vertegenwoordigde.

Mr. Joan Raye ontving op 3 Juni 1735 bericht, dat hij met ingang van de volgende maand benoemd was tot gouverneur van Suriname. Hij vertrok daarheen met zijn secretaris op 25 September, van Amsterdam tot Zaandam uitgeleide gedaan door zijn broeder Jacob, zijn zuster Eva en den echtgenoot van deze, Pieter van Loon,schepen der stad Amsterdam.Na een afscheidsmaaltijd, een vischdiner in de herberg „De Otter”, keerde de familie naar Amsterdam terug en zette de gouverneur met zijn secretaris de reis naar Den Helder,waar hij zich zou inschepen, voort. Met een 
boeier gingen zij naarAlkmaar, overnachtten daar en kwamen den volgenden dag in Den Helder aan. Op de reede van Texel lagen behalve het schip de ,JJacob Daniël”, waarmede Joan Raye de reis zou ondernemen, nog verscheidene andere schepen gereed om te vertrekken, waaronder ook dat van Pieter Versyn, waarmede de eerste Herrnhutter zendelingen, Georg Piesch, Georg Berwick en $\mathrm{H}$. Chr. von Larisch, de reis naar Suriname zouden aanvaarden. Dit schip vertrok op 7 October; den dag daarvóór was de Johan Daniël met gouverneur Raye aan boord onder zeil gegaan. Met de woorden: „God geve haar een goeden Rys” besloot Jacob Bicker Raye de aanteekening daarvan in zijn dagboek. Die wensch ging in vervulling: op 20 December kwam de gouverneur behouden in de kolonie aan. Enkele uren tevoren was het schip der Herrnhutters eveneens voor het Fort Zeelandia aangekomen. Den volgenden dag aanvaardde Joan Raye het bestuur over de kolonie, waar hij o.a. de weduwen van zijn voorgangers, de Douairières De Cheusses, aantrof, nl. de vroegere mejuffrouw Van der Lith, en haar vroegere leerlinge, later stiefdochter, Catharina Eleonora Temminck, die met den gouverneur Jacob Alexander de Cheusses gehuwd geweest was en dus thans ook haar schoonzuster was. De kennismaking met de eerste leidde tot een verloving, gevolgd door het huwelijk te Paramaribo op 2 Maart 1737. Op 20 Mei van dat jaar kwam het bericht van deze gebeurtenis bij de familie te Amsterdam aan, blijkens de aanteekening daarvan door broeder Jacob in zijn dagboek. Voor de derde maal zetelde dus de vroegere gouvernante als echtgenoote van den gouverneur weder als meesteres in het gouvernements-hotel op het Plein te Paramaribo. Uit dit huwelijk werd op 27 November van hetzelfde jaar een zoon geboren, die naar zijn vader den naam van Joan ontving. Mevrouw Raye zond een eigenhandig bericht van deze heuglijke gebeurtenis aan de familie te Amsterdam, waar het op 14 Februari van het volgende jaar aankwam. Jacob Bicker Raye maakte op dien dag de volgende aanteekening in zijn dagboek: ,Zuster Raye is op den 27sten November 1737 zeer voorspoedig en gelukkig bevallen van een welgeschapen, frisschen zoon" ' 1 ).

1) Jacob Raye nam bij zijn eigen familienaam ook dien van zijn moeder aan en is daardoor meer bekend als Jacob Bicker Raye. Hij begon in 1732 met het schrijven van een dagboek, waarin hij datgene, wat hem belangrijk voorkwam, met een korte onderbreking geregeld van dag tot dag opteekende. De titel hiervan is ,Notitie van het Merkwaardigste meyn bekent, 1732-1772'. Het bevat hoofdzakelijk aanteekeningen omtrent familie-aangelegenheden en omtrent personen en gebeurtenissen, vaak zeer alledaagsche, te Amsterdam. z.o.z. 
Mevrouw Raye was toen reeds voor de derde maal weduwe; op 12 Augustus van het zelfde jaar was de gouverneur na een zeer kortstondige ziekte overleden. Den 29sten October werd het bericht van zijn overlijden door de familie te Amsterdam ontvangen. Op echt 18e-eeuwsche, wijdloopige wijze teekende Jacob Bicker Raye dit in zijn dagboek op, en wel aldus:

„,Mijn broeder, de Heer Joan Raye, gouverneur over de Collonie van Suriname, rivieren en districten van dien, Collonel van de Militie en president in alle de Collegies aldaar, mitsgaders Capiteyn ter Zee ten diensten deeser Landen, sorteerende onder het Collegie der Admiraliteyt alhier is op den 11 Augustus 1.1. in den ouderdom van 39 jaar overleden".

Rustig en hemzelf voldoening gevend was zijn bestuur niet geweest. Het werd o.a. gekenmerkt door ernstige verschillen met de Raden van Politie, welke dezen aanleiding gaven, zich met een rekest tot de Staten-Generaal der Republiek te wenden om zich te beklagen over ,de despotique conduites van den nieuwen Gouverneur". Dit gaf dezen laatsten aanleiding in 1737 zijn ontslag te verzoeken. Vóór de beslissing op dit verzoek in Suriname aankwam, was hij echter reeds overleden. Ongetwijteld had hij op een langer verblijf in Suriname gerekend, want reeds kort na zijn aankomst had hij gronden aan de Commewijne aangekocht, waar de thans nog bestaande plantage Breukelerwaard werd aangelegd. De zorg hiervoor kwam thans ten laste van zijn weduwe, die behalve deze ook nog de plantage Berg en Daal aan de Surinamerivier bezat, die zij voor de helft van den gouverneur Temminck geërfd en voor de andere helft van haar stiefdochter gekocht had $\left.{ }^{1}\right)$. Zwager Jacob te Amsterdam had blijkbaar in deze opzichten, respect voor haar werkzaamheid, want hij teekende in zijn dagboek aan, dat ,haar man eerst beesig was een nieuwe plantagie aan te leggen, en op deselve een nieuw suykerwerk te maken, waartoe nog dagelijks de materiaale hier van daan moeten worden

Jacob Bicker Raye was, toen zijn broeder gouverneur van Suriname werd, weduwnaar van Maria Sophia Goossens, met wie hij in Februari 1729 gehuwd was, en die op 2 Juni 1733 overleed, hem als eenigen erfgenaam een bedrag van $f 13.200$ nalatende. Hij ging toen bij zijn moeder inwonen, die haar buitengoed Leeuwenvegt bij Breukelen verkocht had en op de Heerengracht bij de Reguliersgracht woonde.

Eva Raye was in 1730 gehuwd met Pieter van Loon, die in 1736 schepen der stad werd. Het echtpaar Van Loon woonde op de Keizersgracht Noordzijde, bij den Amstel.

1) Zie hierover: Mr. P. Bijlsma. Gouverneur Temming's plantage Berg en Daal, enz. in De West-Indische Gids III blz. 31. 
gesonden bestaande in eenige duysende steenen, houtwerk en eyserwerk".

Was het dus in Suriname reeds allesbehalve rustig geweest, zoolang de latere mevrouw Audra nog als echtgenoote van den gouverneur op het Plein zetelde, nog meer gespannen werd de toestand daar, toen zij haar plaats, die zij zoolang bekleed had, moest afstaan aan haar opvolgster, de echtgenoote van den gouverneur Mauricius. Na gedurende vijf jaren weduwe geweest te zijn, sloot mevrouw Raye op 7 Januari 1742 haar vierde huwelijk, ditmaal met den predikant van de Waalsche gemeente te Paramaribo, Anthony Audra, die ruim twee jaar later, op 17 Mei 1744, overleed. Vier jaren daarna, op 27 Mei 1748 huwde Mevrouw Audra daarna voor de vijfde en laatste maal, ditmaal met den opvolger van Ds. Audra, den predikant Bartholomeus Ludovicus Duvoisin, die op 1 November 1751 stierf. Spoedig na den dood van den gouverneur Raye sloot mevrouw Audra zich bij de oppositie-partij aan, waarvan zij al spoedig de leidster of, zooals Mauricius het uitdrukte, „het orakel” werd, wat zij bleef tot haar dood te Paramaribo op 6 Augustus 1753. Zij werd in het fort Zeelandia begraven. Op 19 October d.a.v. ontving de familie Raye het bericht van haar overlijden en haar gewezen zwager maakte daarvan een notitie in zijn dagboek, waarin hij vermeldde, dat zij ,,een uitnemend verstandige, gauwe vrouw" geweest was, die zelf twee plantages, Breukelerwaard (aan de Commewijne) en Berg en Daal (aan de Surinamerivier) administreerde. Zij was, voegt hij erbij, ,,zonder weerga couragieus en present in de allerswaarste voorvallende gelegenheden".

Haar zoon Joan Raye Jr. was destijds niet meer in Suriname. Op 10-jarigen leeftijd was hij ter voltooiing zijner opvoeding naar Holland gezonden onder geleide van een neef van zijn vader, Mr. Jacob Baron de Petersen, generaal-directeur van Guinea, die naar Holland terugkeerde en de reis daarheen niet rechtstreeks maar over Suriname gemaakt had. Op 13 November 1747 kwam de „Heer” Joan Raye - aldus betitelt zijn oom Jacob hem in zijn dagboek - bij de familie te Amsterdam aan. Deze besteedde de noodige zorg aan haar pupil. Eerst werd hij op een kostschool geplaatst, maar toen hij daar een paar malen ziek was geweest, kwam hij tijdelijk bij zijn oom Jacob in huis.

Na volbrachte studie koos Joan Raye Jr. een diplomatieke loopbaan. Op 18 November 1764, dus op 27-jarigen leeftijd, vertrok hij naar Constantinopel in het gevolg van W. G. Dedel, gezant der Republiek bij de Ottomaansche Porte. Na gedurende vijf jaren 
aan het gezantschap daar verbonden geweest te zijn, keerde hij in 1769 te Amsterdam terug. Op 24 November van dat jaar teekende zijn oom Jacob zijn behouden terugkeer in zijn dagboek aan.

\section{Literatuur}

J. Wolbers, Geschiedenis van Suriname, Amsterdam 1861.

Jacob Bicker Raye, Notitie van het Merkwaardigste Meyn Bekent.

1732-1772. (Bewerking door Dr. M. G. de Boer, Amsterdam 1935). 